\title{
Levels and Interconnections of Project Success in Development Projects by Non-Governmental Organisations (NGOs)
} \begin{abstract}
Purpose - The purpose of this paper is to understand and identify the nature of evaluation criteria, levels and associations among levels of project success in development projects by NGOs in Sri Lanka.

Design/methodology/approach - The setting for this study is Sri Lanka, a country currently recovering from civil war and natural disasters and host to a large number of national and international NGOs involved in development projects. Data collection was conducted using a quantitative survey which obtained 447 responses. Multivariate analysis of data was conducted using confirmatory factor analysis and structural equation modelling.

Findings - The study confirmed overall project success in NGOs could be assessed in three levels; Project Management (PM) success, project success and NGO success. The results conclude there are strong associations among the three levels of project success; moreover, PM success and project success are indispensable for achieving NGO success.

Original Value - This study extends existing research to confirm the presence of three levels of project success and the interconnections among them. These finding can support subsequent research on development projects and support the design of holistic evaluation tools to support project practices in NGOs.
\end{abstract}

Keywords: Project Management Success, Project Success, NGO Success, Development Projects and NGOs

\section{Introduction}

Development projects are aimed at providing support to communities and countries in the form advocacy, health, non-formal education, relief and capacity building (Hermann and Pagé 2016; 
Bagci 2003) at community, national and international levels (Banks et al. 2003; Bagci 2003). These projects are difficult to evaluate as the outcomes are not easily captured with quantitative metrics; in addition, development projects involve a heterogeneous mix of stakeholders (Easterly 2009) who may be from the public sector, private sector and community residents. In these projects, the target customer or beneficiary is a community where boundaries are not clearly defined (Golini and Landoni 2014). Further, the beneficiaries from the project's outputs are usually not funding the project (Ahsan and Gunawan 2010). Recently, there has been an increase in donors' funds, human capital and international bodies engaged in humanitarian development activities (UNDP 2014; Diallo and Thuillier 2005).

NGOs function particularly for humanitarian-oriented activities, which are not addressed by the private or public sectors and focus on direct interaction with the community in advocacy, health, non-formal education, relief and capacity building, etc. (Bagci 2003; Lusthaus et al. 2002; Lyons 2001; CEEDR 2001). NGOs form an essential part in delivery of development projects as they operate in turbulent natural, economic and social environments to support rebuilding vulnerable communities (Weerawardena et al. 2010). NGOs engage with the unique challenges of development projects and coordinate complex groupings of stakeholders to mobilise the resources required to deliver effective services to communities (Yalegama et al. 2016). These characteristics suggest that it is not sufficient only to understand the levels of project success along with the interconnections of project success among these levels.

Sri Lanka’s voluntary sector has a long history (Orjuela 2005; Wanigaratne 1997). Recently, a 30 year long civil war occurred in the country and a number of NGOs were created to respond to community disruption created by this event (DeVotta 2005). Later, a tsunami struck the country 
in 2004, killing around 35,000, displacing one million Sri Lankans and causing economic damage estimated at US\$1,316 million (EM-DAT 2014). Recovery from both of these occurrences has been aided by international support channelled through various funding agencies (Yalegama et al. 2016; National Secretariat for Non-Governmental Organizations 2012). Therefore, the context of development projects in Sri Lanka is highly distinctive and an appropriate location for studying NGOs’ development projects and the evaluation criteria of project success.

Evaluation of project success is critical for NGOs to both show performance (Camilleri 2012) and demonstrate accountability to stakeholders, which can enhance their fund mobilising ability, enabling these organizations to sustain activities in communities (Golini et al. 2014; Hermano et al. 2013; Ika et al. 2012). However, project success is a multi-dimensional domain that incorporates a range of factors and levels, a perspective that has been overlooked in examining development projects involving NGOs. Therefore, the study aims to identify the evaluation criteria of project success, understand the levels of project success of NGOs involved in development projects and identify the associations existing among the levels of project success in NGOs. 


\section{Literature Review}

\subsection{Evolution of Perspectives on Project Success}

Early conceptualizations of evaluation criteria of project success focused on the achievements of defined objectives or outcomes, such as time, cost and quality (Westhuizen and Fitzgerald 2005). Currently, a broader range of criteria, including stakeholder satisfaction (Baccarini 1999; Schwalbe 2004), product success, business and organisational benefit (Globerson and Zwikael 2002; Thomsett 2002; Redmill 1997) team development (Atkinson 1999; Baccarini 1999) and the quality of PM process (Ika et al. 2012), is being incorporated. Previous research emphasised the levels of project success in private sector organisations; however, the context of development projects in an NGO setting are very rarely researched. NGOs' activities are project-based and currently extend to all sectors of social life, such as relief, welfare, development programs, environmental issues, human rights, democracy building, conflict resolution, cultural preservation and many other areas of socio-economic development (Ika 2012; Lewis and Kanji 2009; Bagci 2003; Korten 1990). The unique requirements of NGOs may also be reflected in how project success is evaluated by these organizations. The researcher focused on literature concerning assessment of development projects and other private sector projects to develop a conceptual idea of how project success is evaluated in different sectors (Ika 2012; Diallo and Thuillier 2004; Cooke-Davies 2002).

De Wit (1988) and Cooke-Davies (2002) classified project success into the connected domains of project management success (cost, time and quality) and project product success (benefits derived from use of a project's outputs) (Pinkerton 2003). Four distinct dimensions of project success were identified by Shenhar et al. (1997): project efficiency, customer impact, 
organizational success, and future orientation. Current research reflects this multi-dimensional approach (ul Musawir, Serra, Zwikael and Ali 2017). Research has identified dimensions of project management success, repeatable project management success, project success (Sutton 2005), and corporate success (Cooke-Davies 2002). Hence, project success is defined holistically and project delivery is linked to overall organisational success.

\subsection{Levels and Evaluation Criteria of Development Project Success}

In complex, uncertain projects such as development projects, success or failure are not binary outcomes (Sutton 2005) and degrees of success and failure can exist. The multi-dimensional nature of development project success was identified by Diallo and Thuillier (2004) who examined the perceptions of seven groups of stakeholders: coordinators, task managers, supervisors, project team, governance team, beneficiaries and country residents. Evaluation

criteria were also identified, such as beneficiary satisfaction, project outputs delivered to agreed standards, traditional iron triangle elements of time and budget and positive perception of the project by external stakeholders. Table 1 summarises extant research of levels of project success in development projects by non-profit organisations and other private sector projects. 
Table 1: Levels of Project Success

\begin{tabular}{|c|c|c|c|c|}
\hline $\begin{array}{l}\text { Levels of } \\
\text { Success }\end{array}$ & Explanations & Evaluation Criteria & $\begin{array}{l}\text { Development Projects by } \\
\text { Non-profit organizations }\end{array}$ & Other Private Sector Projects \\
\hline PM Success & $\begin{array}{l}\text { Development project } \\
\text { creates desired outputs. } \\
\text { Development projects are } \\
\text { completed according to } \\
\text { planned time, budget, } \\
\text { quality and scope } \\
\text { parameters. }\end{array}$ & $\begin{array}{l}\text { Time } \\
\text { Budget } \\
\text { Quality }\end{array}$ & $\begin{array}{l}\text { Njeri and Were 2017; Ika 2012; } \\
\text { Ika 2009; Diallo and Thuillier } \\
2004\end{array}$ & $\begin{array}{l}\text { Berssaneti and Carvalho 2015; } \\
\text { Papke-shields et al. 2010; Agarwal } \\
\text { and Rathod 2006; Westhuizen and } \\
\text { Fitzgerald 2005; Dvir et al. } 2003 \\
\text { Thomsett 2002; Cooke-Davies } \\
\text { 2002; Globerson and Zwikael } \\
\text { 2002; Atkinson 1999; Baccarini } \\
\text { 1999; Redmill 1997; Blaney 1989; } \\
\text { De Wit 1988; Duncan 1987. }\end{array}$ \\
\hline
\end{tabular}




\begin{tabular}{|c|c|c|c|c|}
\hline $\begin{array}{l}\text { Project } \\
\text { Success }\end{array}$ & $\begin{array}{l}\text { Development projects' } \\
\text { outputs deliver the } \\
\text { desired outcomes. }\end{array}$ & $\begin{array}{l}\text { Customers/Stakeholders' } \\
\text { Satisfaction } \\
\text { Project impacts } \\
\text { Project sustainability } \\
\text { Contribution to } \\
\text { development objectives }\end{array}$ & $\begin{array}{l}\text { Ika et al. 2012; Ika 2012; Ika } \\
\text { 2009; Diallo and Thuillier 2004; }\end{array}$ & $\begin{array}{l}\text { Serra and Kunc 2015; Serrador } \\
\text { 2013; Zwikael and Smyrk 2012; } \\
\text { McLeod et al. 2012; Sutton 2005; } \\
\text { Schwalbe 2004; Schwalbe 2004; } \\
\text { Pinkerton 2003; Jiang, Klein \& } \\
\text { Discenza 2002; Globerson and } \\
\text { Zwikael 2002; Cooke-Davies 2002; } \\
\text { Thomsett 2002; Baccarini 1999; } \\
\text { Shenhar, Levy and Dvir 1997; } \\
\text { Redmill 1997; De Wit 1988; Pinto } \\
\text { and Slevin 1988; Tuman 1986. }\end{array}$ \\
\hline $\begin{array}{l}\text { NGO } \\
\text { Organizational } \\
\text { Success }\end{array}$ & $\begin{array}{l}\text { Development projects' } \\
\text { outputs and outcomes } \\
\text { contributes to the overall } \\
\text { success of the NGO }\end{array}$ & $\begin{array}{l}\text { Achieving organisational } \\
\text { vision, mission and } \\
\text { objectives } \\
\text { Stakeholders' reputation } \\
\text { and rapport } \\
\text { Sustainability }\end{array}$ & Ika et al. 2012; Ika 2012; & $\begin{array}{l}\text { Serra and Kunc 2015; McLeod et } \\
\text { al. 2012; Dvir et al. 2003; Cooke- } \\
\text { Davies 2002; Shenhar, Levy and } \\
\text { Dvir } 1997\end{array}$ \\
\hline
\end{tabular}


Whilst Ika et al. (2012) used factors comprising time, cost, objectives, relevance, impact and sustainability to evaluate the project success of World Bank projects, evaluation criteria can occur at multiple levels (Cooke-Davies 2002). Although there is a significant amount of research of factors and criteria, association among levels of project success is not yet known. The aim of this research is to identify relationships among the levels of project success (Hoyle 1995).

\subsection{Conceptual Framework and Hypotheses}

Models proposed by Cooke-Davies (2002) and Sutton (2005) categorised project success into three levels, which are Project Management and Project and Organizational Success. Project management success focuses on completing the project within the traditional parameters of time, budget and quality to assess project efficiency and outputs of projects in the short term. From the NGOs' perspective, assessment is not limited to the first level of delivering projects within time, budget, scope and quality parameters because NGOs are required to be accountable to stakeholders by showing how well donors’ funds well produced impacts to the community (Ika and Donnelly 2017; Salafsky and Margoluis 1998). In practice, these levels may be linked but the extent to which this occurs in NGOs is not yet known. Hypothesis 1 is:

H1: PM success directly contributes to NGO perceptions of development project success

Project success broadly assesses stakeholders' satisfaction and impacts of projects on the community. This evaluates the outcomes in the medium term in areas such as stakeholders' satisfaction with the broad and sustained positive impacts in the community. Meeting the abovestated assessment criteria may ensure future funding from the donors (Baker 2000).

H2: PM success directly contributes to NGO success 
This evaluates how project outcomes impact on NGO strategy and success (Aldashev and Verdier 2009; Ly and Mason 2012). This area is of great interest for NGOs as they are required to compete for donor and state funding geographically (community vs international NGOs) and for some services, with private organizations (Nanthagopan et al. 2016). Therefore, assessment criteria for NGOs' projects need to examine how NGO projects support achievement of the NGO's vision, mission and objectives, how they improve the reputation and stakeholders' rapport and how they will contribute to the NGO's sustainability (Nanthagopan and Williams 2016). The proposed conceptual model is shown in Figure 1. Hypothesis 3 is therefore:

H3: Project success directly contributes to NGO success

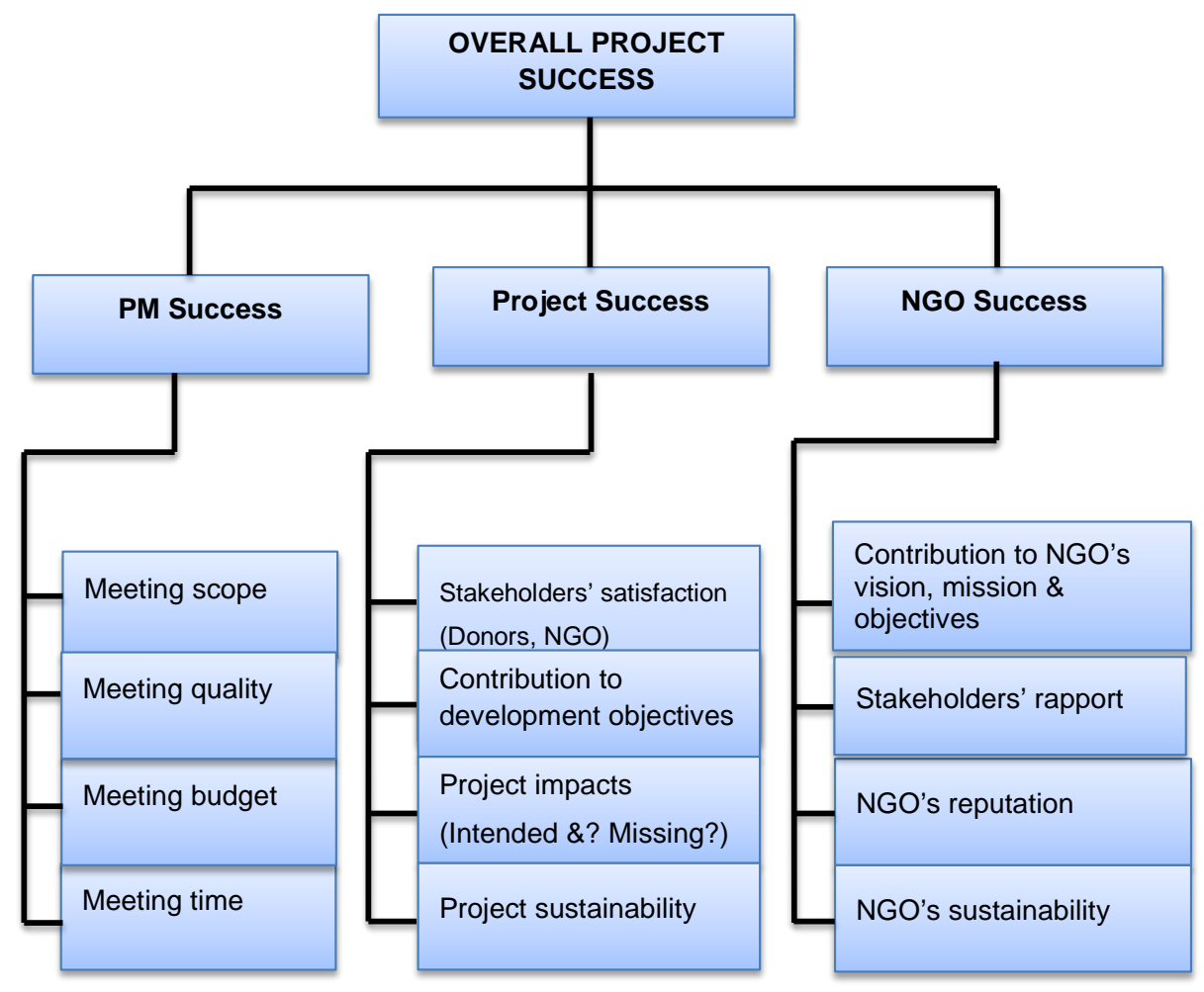

Figure 1: Three levels of Project Success 


\section{Research Methods}

The aim of this study is to develop an understanding of the nature of evaluation criteria for project success and to identify the association among levels of project success in NGOs. Statistical software packages were used to analyse the final survey data. The Statistical Package for Social Sciences (SPSS v16) was used for preliminary data analyses (Hopkins 2008) and Analysis of Moment Structures (AMOS v21) was used analyse the measurement model and test the hypothesised model (Byrne 2013). Univariate and multivariate analyses were used to examine the variables in the study. In statistical analyses, the first step is to understand the data set by examining individual variables using univariate analyses techniques to summarise the data and analyse the individual variables (Bryman and Cramer 2009) and multivariate analysis to analyse relationships of the multiple variables at once (Byrne 2010; Abdi 2003). Commonly, multivariate procedures are recommended if the study has multiple variables and requires identifying associations between variables (Byrne 2010; Abdi 2003).

This study is primarily oriented to understand the nature of evaluation factors for project success and identifying associations among the multiple variables; therefore, the researcher applied two main multivariate techniques: Confirmatory Factor Analysis (CFA) and Structural Equation Modelling (SEM) (Byrne 2013). SEM is now used in many fields of study since it is widely recognised as an important multivariate technique when studying relationships among latent constructs consisting of multiple indicators (Hair et al. 2006; Cooper and Schindler 2003). However, levels of project success were not examined by the SEM technique in the literature. Further, project success assessment criteria applicable to development projects by NGOs has been researched rarely and has not been examined empirically using multivariate analysis techniques. This is a new initiative for using the multivariate techniques CFA and SEM 
according to the literature, as this study demands use of these techniques for testing and identifying associations among the levels of project success.

\subsection{Justification and Selection of CFA and SEM}

CFA is generally applied to understand the associations between observed variables and underlying latent constructs (Brown 2014; Bryne 1994). As CFA is used to examine that the measures of constructs are consistent with the literature, it is applied in this study to evaluate the overall measurement model based on the latent constructs of project success.

SEM is used to determine whether theoretical models are valid using empirical data (Lei and Wu 2007). SEM has been deployed to identify hypothetical relationships between organisational factors and project complexity (Qureshi and Kang 2015). The present study is undertaken in the new context of NGOs and aims to understand the evaluation factors of project success and identifies associations among the levels of project success. Therefore, it requires the highly sophisticated SEM technique for testing proposed relations among latent constructs and assessing structural model validity for model development (Hair et al. 2006; Stephenson et al. 2006). SEM can determine associations among levels of project success of NGOs. The primary role for SEM in this study is to derive a model which explains relationships among the levels of project success (Hoyle 1995).

\subsection{Data Collection}

Data was collected using a self-administered structured questionnaire (Mazzocchi 2008; Hair et al. 2003) (Appendix 2). The questionnaire followed the validated survey instruments of Ika et al. 
(2012), Diallo and Thuillier (2004) and De Wit (1988), modified to suit the context of respondents relevant to NGO development projects in Sri Lanka (Appendix 1). The researcher conducted the pilot study with 30 respondents from the target population of NGOs in order to ensure the adequacy and credibility of the survey instrument and that the research protocols and methods could work well (Thabane et al. 2010; Lancaster et al. 2004; Teijlingen, and Hundley 2002). The pilot study indicated that the instrument was reliable and valid. The final survey instrument consists of 12 questions to assess NGOs' project success. The questionnaire comprised three divisions: PM success, Project success and NGO success, with each division consisting of four questions. A seven-point Likert scale is used in this study for assessing the study variables (Judgev 2006) since it is recommended for increasing the quality of data characteristics. Such a longer discrete scale acts slightly more like a continuous scale and this permits effective performance of statistical parametric and factor analysis (Preston and Colman 2000; Hinkin 1998).

The researcher selected the 'in-person' method of data collection in order to increase the credibility of data collection as it made it possible for respondents to get additional details and clarification on the nature of the study (Bowling 2005). However, the researcher did not interrupt respondents while they were completing the questionnaire. Firstly, the researcher contacted managers of selected organisations by telephone or mail to inform them of the research objectives of the study and to receive their consent for this study. Thereafter, he delivered the questionnaire in person and collected completed questionnaires from respondents, which improved the quality of data collection and increased response rates (Bowling 2005). 


\subsection{Sampling Procedure}

1,426 NGOs are registered in Sri Lanka with the National Secretariat for NGOs, of which 1,042 are local NGOs and 384 are international NGOs (National Secretariat for NGOs 2014). For this research, the sample size was 500 local and international NGOs, which represents 35\% of the population. The selection of the sample size was based on the designated statistical analysis technique, structural equation modelling, which requires the largest possible sample size (Chin and Newsted 1999). As the study population contained both local and international NGOs, a stratified random sampling technique was used to select a representative sample in equal proportions from each stratum (Levy and Lemeshow 2009). By selecting a randomised probabilistic sample, it was possible to increase the generalisability of the survey findings to the population (Levy and Lemeshow 2009). The researcher contacted 500 NGO managers, of which 463 managers indicated their interest. 447 questionnaires were filled out but 16 questionnaires were eliminated based on incomplete data. Local NGOs represent 73\% (327) of the sample size and $27 \%$ (120) represent international NGOs. The local NGOs represent $31.4 \%$ and the international NGOs represent $31.1 \%$ of the total individual populations.

Projects are classified under 11 categories, which are Livelihoods, Infrastructure, Relief and Disaster Management, Water and Sanitation, Health and Nutrient, Training and Education, Protection, Social Mobilisation, Capacity Building, Women Development, Gender Equity and Others. The Livelihoods and Training and Education projects are highly represented with 31\% included in the sample whilst the Gender Equity and Women Development categories are less represented with $11 \%$ in the sample. Other project categories' contributions range between $7 \%$ and $10 \%$ of the sample. Project managers' experience in NGO projects is categorised as $0-5$ 
years, 6-10 11-15 16-20 and 20 years and above working in NGO projects. Managers having experience $0-5$ and 6-10 years are represented highly as $68 \%$ of the sample whilst those with 11 15 years represent $17 \%$. Other categories are represented in approximately equal contributions. Education of selected NGO managers is organised as High School, Bachelor's Degree, Postgraduate Degree, and Doctoral Degree. NGO managers holding a bachelor's degree are highly represented at $45 \%$ in the sample, followed by higher education at $32 \%$ and postgraduate degree at $22 \%$. Those managers holding a doctoral degree contributed the least (1\%) of the sample. Some $77 \%$ of NGO managers responded that they have undertaken PM courses and 20\% stated they have not undertaken any PM courses, leaving 3\% that did not respond to this question. 


\section{Survey Study Results}

\subsection{Descriptive Statistics}

Descriptive statistics related to central tendency, dispersion and normal distribution of survey measures were calculated (Mazzocchi 2008). Project success is divided into three levels of PM success, project success and NGO success and four items were used to evaluate each level of project success. Table 3 presents the descriptive results for all items.

All items of PM success assessment factors achieved high mean values: meeting scope 5.31 ( \pm 1.19$)$, meeting quality $5.24( \pm 1.18)$, meeting time $5.20( \pm 1.31)$ and meeting budget 5.09 ( \pm 1.30 ). Next, in project success, stakeholders’ satisfaction (mean score $5.28, \pm 1.23$ ) and project sustainability (mean score $5.28, \pm 1.30$ ) achieved high mean values, whilst contribution to development objectives (mean score 4.76, \pm 1.54 ) and project impacts (mean score 4.76, \pm 1.41 ) scored lower mean values. Finally, in NGO success, contribution to NGOs' vision, mission and objectives (mean score $5.58, \pm 1.17$ ) and NGOs’ reputation (mean score $5.45, \pm 1.20$ ) achieved high mean values. Stakeholders’ rapport (mean score $4.82, \pm 1.60$ ) and NGO sustainability (mean score 4.94, \pm 1.41 ) scored lower mean values.

The data set is a representative sample of the total population of NGOs, having used a stratified random sampling technique. The data mean and median values are in the range 4-6, which shows NGOs’ development projects success rates are middling in Sri Lanka. Further, skewness and kurtosis values for all items lie between -1 and +1 ; therefore, all levels of project success items closely meet univariate normality (Garson 2012). Accordingly, the data is adequate for conducting multivariate analysis (Hair et al. 2006). 
Table 3: Project Success (N 447)

\begin{tabular}{|c|c|c|c|c|c|c|}
\hline Types of Project Success & Mean & Median & Mode & $\begin{array}{c}\text { Std. } \\
\text { Deviation }\end{array}$ & Skewness & Kurtosis \\
\hline \multicolumn{7}{|l|}{ PM Success } \\
\hline Meeting Scope (Q1) & 5.31 & 6.00 & 6.00 & 1.19 & -0.64 & 0.13 \\
\hline Meeting Quality (Q2) & 5.24 & 5.00 & 6.00 & 1.18 & -0.60 & 0.28 \\
\hline Meeting Time (Q3) & 5.20 & 5.00 & 6.00 & 1.31 & -0.58 & -0.17 \\
\hline Meeting Budget (Q4) & 5.09 & 5.00 & 6.00 & 1.30 & -0.56 & -0.08 \\
\hline \multicolumn{7}{|l|}{ Project Success } \\
\hline Stakeholders' Satisfaction (Q5) & 5.28 & 6.00 & 6.00 & 1.23 & -0.86 & 0.58 \\
\hline $\begin{array}{l}\text { Contribution to Development } \\
\text { Objectives (Q6) }\end{array}$ & 4.76 & 5.00 & 6.00 & 1.54 & -0.37 & -0.71 \\
\hline Project Impacts (Q7) & 4.76 & 5.00 & 6.00 & 1.41 & -0.59 & -0.25 \\
\hline Project Sustainability (Q8) & 5.23 & 5.00 & 6.00 & 1.30 & -0.76 & 0.33 \\
\hline \multicolumn{7}{|l|}{ NGO Success } \\
\hline $\begin{array}{l}\text { Contribution to NGOs' Vision, } \\
\text { Mission \& Objectives (Q9) }\end{array}$ & 5.58 & 6.00 & 6.00 & 1.17 & -0.64 & -0.06 \\
\hline Stakeholders' Rapport (Q10) & 4.82 & 5.00 & 6.00 & 1.60 & -0.47 & -0.70 \\
\hline NGO Reputation (Q11) & 5.45 & 6.00 & 6.00 & 1.20 & -0.64 & -0.24 \\
\hline NGO Sustainability (Q12) & 4.94 & 5.00 & 6.00 & 1.41 & -0.53 & -0.30 \\
\hline
\end{tabular}

\section{2: Specification of Measurement Model for Project Success}

CFA Model 1 (Figure 2) was drawn based on the findings from an exploratory case study and literature review. The findings explained the indicators of the latent factors. The first factor, PM Success, consists of four indicators: Q1, Q2, Q3 and Q4; the second factor, Project Success, 
consists of four indicators: Q5, Q6, Q7 and Q8; and the third factor, NGO Success, consists of four indicators: Q9, Q10, Q11 and Q12.

The results for the absolute fit indices show the normed chi-square ( $\chi 2$ / df) value is 4.501 , GFI is 0.967, RMSEA is 0.089, P Close value is less than 0.05 and SRMR is 0.044 . The incremental indices results show NFI is 0.922 , TLI is 0.920 and CFI is 0.938 . The parsimonious fit indices results indicate AGFI is 0.877 and PNFI is 0.712 . The results for these three indices demonstrate the model is a poor fit (Hu and Bentler 1999; Byrne 1994; Wheaton 1987). AVE values for the latent factors of PM Success (PM) and NGO Success (NGO) were satisfactory, as were the latent CR values (Hair et al. 2010; Farrell 2010). 
Table 4: Estimates for CFA Model 1

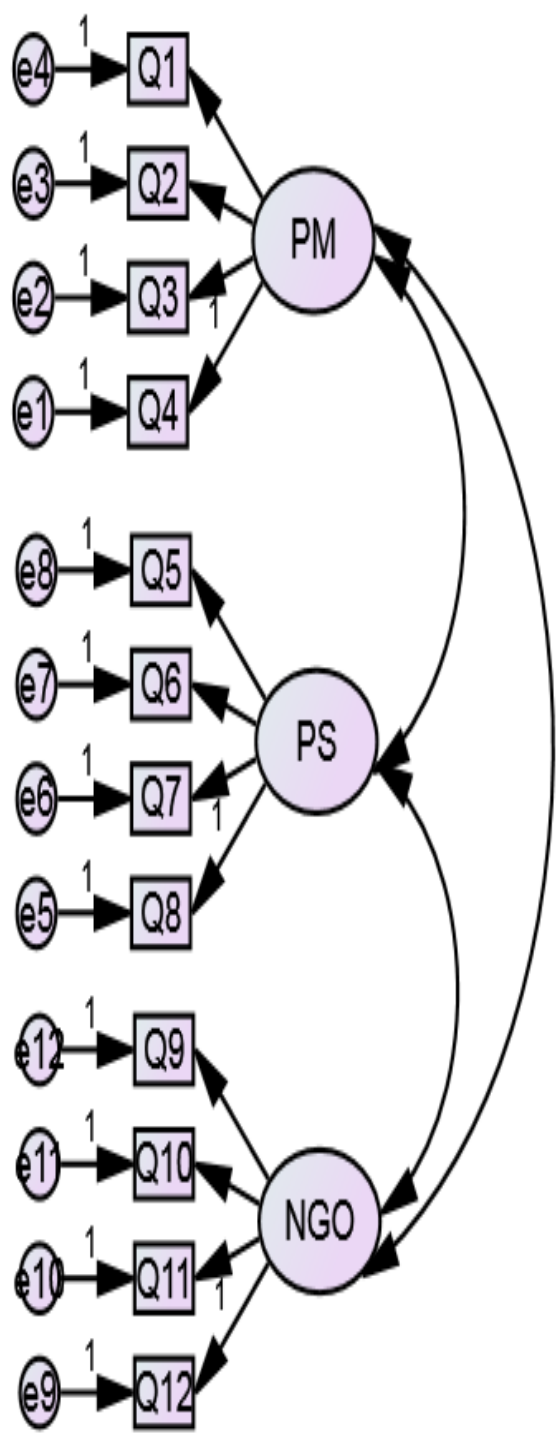

Figure 2: CFA Model 1

\begin{tabular}{|c|c|c|c|c|}
\hline \multirow[t]{2}{*}{ Construct } & \multirow[t]{2}{*}{ Item } & \multicolumn{3}{|c|}{ Standardised } \\
\hline & & PM & PS & NGO \\
\hline \multirow{4}{*}{$\begin{array}{l}\text { PM Success } \\
\text { (PM) }\end{array}$} & Q1 & 0.85 & & \\
\hline & Q2 & 0.80 & & \\
\hline & Q3 & 0.76 & & \\
\hline & Q4 & 0.71 & & \\
\hline \multirow{4}{*}{$\begin{array}{l}\text { Project } \\
\text { Success } \\
\text { (PS) }\end{array}$} & Q5 & & 0.77 & \\
\hline & Q6 & & 0.56 & \\
\hline & Q7 & & 0.60 & \\
\hline & Q8 & & 0.76 & \\
\hline \multirow{4}{*}{$\begin{array}{l}\text { NGO } \\
\text { Success } \\
\text { (NGO) }\end{array}$} & Q9 & & & 0.83 \\
\hline & Q10 & & & 0.60 \\
\hline & Q11 & & & 0.83 \\
\hline & Q12 & & & 0.61 \\
\hline $\begin{array}{l}\text { Average } \\
\text { Variance } \\
\text { Extracted } \\
\text { (AVE) }\end{array}$ & & 0.61 & 0.46 & 0.53 \\
\hline $\begin{array}{l}\text { Construct } \\
\text { Reliability } \\
\text { (CR) }\end{array}$ & & 0.86 & 0.77 & 0.82 \\
\hline $\begin{array}{l}\text { Absolute Fit } \\
\text { Index }\end{array}$ & \multicolumn{4}{|c|}{$\begin{array}{l}x^{2}=229.5, d f=51, x^{2} / d f= \\
4.501, \text { GFI }=0.919, \\
\text { RMSEA }=0.089, \text { P Close }< \\
0.05, \text { SRMR }=0.044\end{array}$} \\
\hline $\begin{array}{l}\text { Incremental } \\
\text { Fit Index }\end{array}$ & \multicolumn{4}{|c|}{$\begin{array}{l}\mathrm{NFI}=0.922, \mathrm{TLI}=0.920 \\
\mathrm{CFI}=0.938\end{array}$} \\
\hline $\begin{array}{l}\text { Parsimony } \\
\text { Fit Index }\end{array}$ & \multicolumn{4}{|c|}{$\mathrm{AGFI}=0.877, \mathrm{PNFI}=0.712$} \\
\hline
\end{tabular}




\section{3: Elimination of Items for CFA Model 1}

Table 5 shows the regression weights of indicators and factors in the CFA Model 1, which give poor results and the researcher therefore checked the high SRC items for elimination. The Q6 factor loading is less than 0.6 and its SRC value is greater than 1.96 with item Q4; therefore, the item has been considered for elimination in order to improve the measurement model fit. (Schumaker and Lomax 2004).

Table 5: Elimination of Items for CFA Model 1

\begin{tabular}{|c|c|c|c|l|}
\hline \multirow{2}{*}{ Items } & \multirow{2}{*}{ Loadings } & \multicolumn{2}{|c|}{ SRCs } & \multicolumn{1}{c|}{ Elimination and Justification } \\
\cline { 3 - 5 } & & $\mathbf{> 1 . 9 6}$ & $\mathbf{2 2 . 5 8}$ & \\
\hline Q6 & 0.56 & 1 & 0 & $\begin{array}{l}\text { Removed / Low loadings + One SRCs > 1.96 } \\
\text { (with Q4) }\end{array}$ \\
\hline
\end{tabular}

\subsection{CFA Model 2: Three Levels of Project Success}

Model 2 (Figure 3) was drawn after eliminating high SCR item Q6. PM success consists of items Q1, Q2, Q3 and Q4 whilst Project success consists of items Q5, Q7 and Q8 and NGO success consists of items Q9, Q10, Q11 and Q12.

The results for the absolute fit indices show a normed chi-square ( $\left.x^{2} / \mathrm{df}\right)$ value of 2.948 , the GFI is 0.942 , the RMSEA is 0.079 , a P Close value of less than 0.05 and the SRMR is 0.035 . Incremental indices results show NFI is 0.943 , TLI is 0.943 and CFI is 0.957 . The parsimonious fit indices results indicate AGFI is 0.907 and PNFI is 0.703 , which indicates a good fit model as this normed chi-square value is less than 3.0 (Wheaton 1987; Carmines and McIver 1981), RMSEA is less than 0.08 and P Close is greater than 0.05 (MacCallum, Browne and Sugawara 
1996). In addition, CFI is greater than the cut-off value 0.90 and SRMR is less than the cut-off value 0.08 (Hu and Bentler 1999).

Furthermore, the CFA results indicate that each factor loading for the reflective indicators is statistically significant at the 0.001 level. AVE values for the latent factors are all acceptable with a significance level greater than 0.5 (Hair et al. 2010). In addition, all CR values were satisfactory at greater than 0.70 (Hair et al. 2010; Farrell 2010); therefore, the researcher accepted this model and used it to proceed to the next step to SEM. 


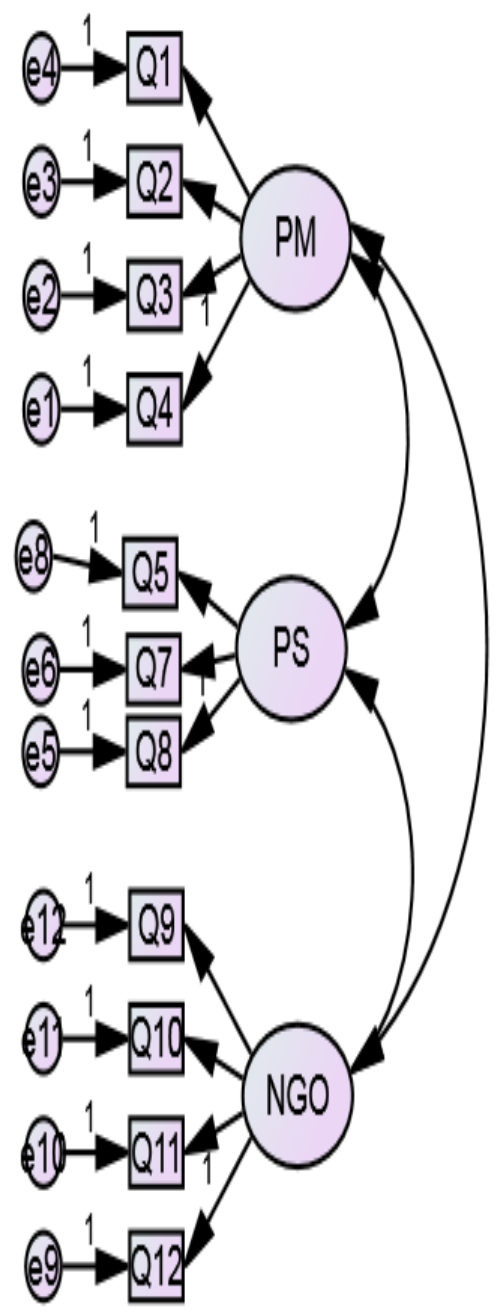

Figure 3: CFA Model 2

\begin{tabular}{|c|c|c|c|c|}
\hline \multirow[t]{2}{*}{ Construct } & \multirow[t]{2}{*}{ Item } & \multicolumn{3}{|c|}{ Standardised Factor } \\
\hline & & PM & PS & NGO \\
\hline \multirow{4}{*}{$\begin{array}{l}\text { PM Success } \\
\text { (PM) }\end{array}$} & Q1 & 0.85 & & \\
\hline & Q2 & 0.80 & & \\
\hline & Q3 & 0.76 & & \\
\hline & Q4 & 0.70 & & \\
\hline \multirow{3}{*}{$\begin{array}{l}\text { Project } \\
\text { Success (PS) }\end{array}$} & Q5 & & 0.78 & \\
\hline & Q7 & & 0.61 & \\
\hline & Q8 & & 0.76 & \\
\hline \multirow{4}{*}{$\begin{array}{l}\text { NGO Success } \\
\text { (NGO) }\end{array}$} & Q9 & & & 0.83 \\
\hline & Q10 & & & 0.59 \\
\hline & Q11 & & & 0.84 \\
\hline & Q12 & & & 0.61 \\
\hline $\begin{array}{l}\text { Average } \\
\text { Variance } \\
\text { Extracted } \\
\text { (AVE) }\end{array}$ & & 0.61 & 0.52 & 0.53 \\
\hline $\begin{array}{l}\text { Construct } \\
\text { Reliability } \\
\text { (CR) }\end{array}$ & & 0.86 & 0.76 & 0.81 \\
\hline $\begin{array}{l}\text { Absolute Fit } \\
\text { Index }\end{array}$ & \multicolumn{4}{|c|}{$\begin{array}{l}x^{2}=120.9, \mathrm{df}=41, x^{2} / \mathrm{df}= \\
2.948, \mathrm{GFI}=0.942, \mathrm{RMSEA}= \\
0.079 \\
\mathrm{P} \text { Close }<0.05, \text { SRMR }=0.035\end{array}$} \\
\hline $\begin{array}{l}\text { Incremental } \\
\text { Fit Index }\end{array}$ & \multicolumn{4}{|c|}{$\begin{array}{l}\mathrm{NFI}=0.943, \mathrm{TLI}=0.943, \mathrm{CFI} \\
=0.957\end{array}$} \\
\hline $\begin{array}{l}\text { Parsimony Fit } \\
\text { Index }\end{array}$ & \multicolumn{4}{|c|}{$\mathrm{AGFI}=0.907, \mathrm{PNFI}=0.703$} \\
\hline
\end{tabular}




\subsection{SEM: Three Levels of Project Success}

After achieving a good fit for the measurement model, the next step is to test the hypothesised causal relationships among the constructs of the model. SEM is used to test the hypothesised causal relationships. SEM provides a more appropriate inference framework for mediation analyses and for other types of causal analyses, as well as helping to develop sound theoretical frameworks through rigorous testing (Hoe 2008). The SEM process consists of two steps, which are validating the measurement model and fitting the structural model. The former is accomplished primarily through CFA, whilst the latter is accomplished primarily through path analysis with latent indicators.

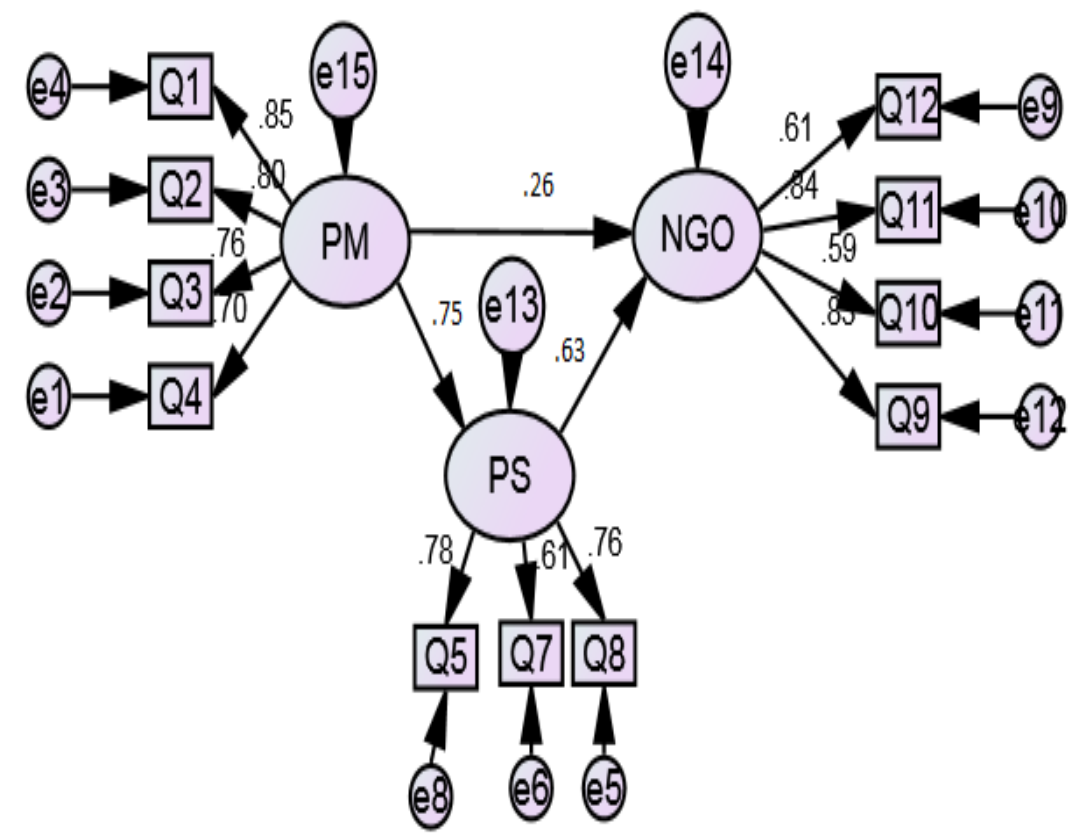

Figure 4: SEM Model 
Table 7: Estimates for SEM Model

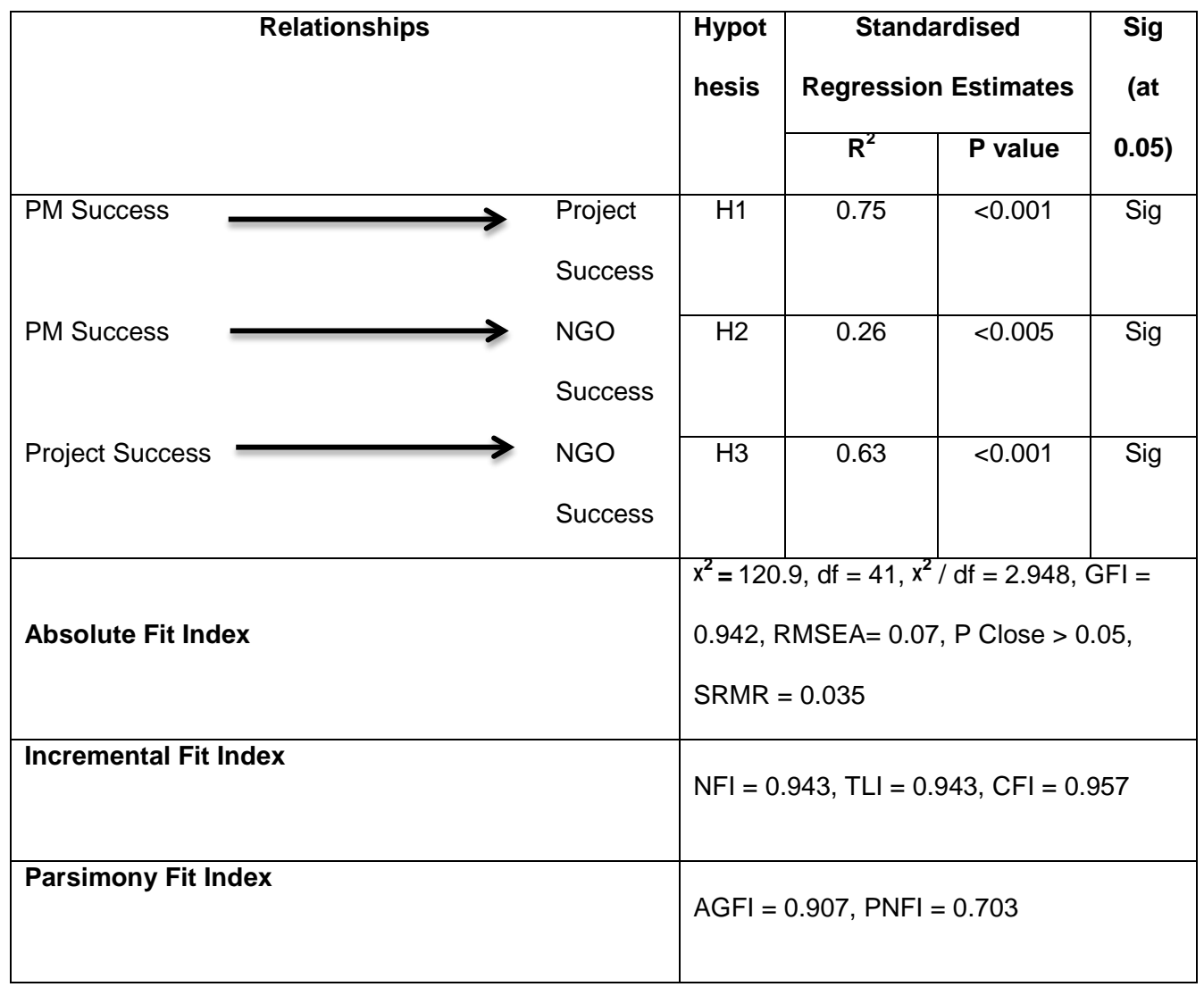

\section{Analysis and Discussion}

Existing research on projects success has been conducted extensively in both private and public-sector firms. This research sought to contribute to the literature by examining Project success of NGOs' development projects at three levels, PM success, Project success and NGO success (Sutton 2005; Pinkerton 2003; Shenhar et al. 1997). The first level is PM success, which examines meeting parameters of scope, quality, time and cost. The second level is project success, which examines stakeholders' satisfaction and project impacts and the third level is NGO success, which examines how projects support achievement of NGOs' objectives and further to contribute to NGOs being sustained a long time in the community. 
The next section compares and discusses the survey study findings with previous research findings.

\subsection{Measuring PM Success}

PM success refers to how projects are completed according to planned time, budget, quality and scope parameters (Shenhar et al. 2001; Baccarini 1999). The PM literature has extensively discussed these four elements, which are used to evaluate project success in private, public and international projects (Berssaneti and Carvalho 2015; Ika et al. 2012; Shenhar et al. 2002; Belassi and Tukel 1996; Pinto and Slevin 1988; De Wit 1988). However, this study has provided empirical validation of the applicability of these measures to development projects. The survey findings confirmed the literature for measuring PM success with the support of four factors, namely, scope, quality, time and budget.

Scope is a measure used to evaluate PM success (Baccarini 1999; Shenhar et al. 2001; Atkinson 1999; Maloney 1990). The study shows that the standardised factor loading for scope is $\mathrm{r}^{2}=0.85(\mathrm{p}<0.001)$ in PM success, confirming that scope is an important factor in NGO projects. Quality is the next factor used to evaluate PM success (Shenhar et al. 2001; Tukel and Rom 2001; Kometa et al. 1995). The study shows that the standardised factor loading for quality is $\mathrm{r}^{2}=0.804(\mathrm{p}<0.001)$ in NGOs’ PM success, indicating it is an important factor. Time is the next factor used to evaluate PM success (Baccarini 1999; Shenhar et al. 2001; Atkinson 1999; Maloney 1990). NGOs schedule the time frame for project activities and completion of the project. However, projects may not be completed on time because NGOs face a high degree of uncertainty and they can be delayed due to unexpected circumstances, such as natural disasters, bad weather, conflict and restrictions imposed on 
access to project areas. This may influence the time outcomes, resulting in the slight factor loading for time, $\mathrm{r}^{2}=0.76(\mathrm{p}<0.001)$ in PM success.

Finally, budget is used to evaluate PM success (Cooke-Davies 2002; Hartman 2000; Baccarini 1999; De Wit 1988). In a similar manner to time, NGOs budgets may change over the project period, as circumstances change in community needs and requirements. This may result in the slightly lower factor loading for budget of $r^{2}=0.71(p<0.001)$ in PM success, when compared to scope and quality.

Scope, quality, time and budget were used to assess PM success, as identified by previous researchers in private and public-sector organisations. Therefore, this explains the four identified elements are common for assessing PM success of enterprises, which suggests the body of PM knowledge developed over the last few decades can be applied to the NGO sector to create useful insights to researchers and managers in this domain.

\subsection{Measuring Project Success}

Project success refers to the degree to which development projects' outputs produce the desired outcomes. Previous studies have identified stakeholders’ satisfaction, project impacts, contribution to development objectives and project sustainability as factors used to evaluate project success (Serra and Kunc 2015; Diallo and Thuillier 2005 2004; Cooke-Davies 2002; Shenhar et al. 2001). However, the survey study eliminated one item called contribution to development objectives, as this factor's loading was low and it had high cross loadings. The survey study identified three underlying elements for use in evaluating NGOs' project success, which are stakeholders' satisfaction, project impacts and project sustainability in the community. 
Stakeholders' satisfaction is the first important factor used to evaluate project success. In PM literature it is widely acknowledged that customers' satisfaction is an important element for evaluating project success in private sector organisations (Cooke-Davies 2002; Torbica and Stroh 2001; Liu and Walker 1998). NGO objectives are to fulfil community needs within the constraints set by the requirement to be accountable to other stakeholders, such as government bodies, donors, and other NGOs who work with them in similar projects. Therefore, they need to try to fulfil the requirements of all stakeholders, which may result in a standardised factor loading for stakeholders' satisfaction of $r^{2}=0.76(p<0.001)$ in project success.

Secondly, the study revealed evaluating the intended and unintended impacts of projects is an important measure for evaluating project success, as emphasised in previous studies (Diallo and Thuillier 2005 2004; Shenhar et al. 2001). Development projects are designed to provide long-term benefits to the community, which can include the promotion of community resilience that assists the community in leading themselves to live a better life. For example, if an NGO undertakes capacity development projects in the community, the NGO would see PM success as a way of evaluating successful completion of projects in the first instance. However, it is also highly important to assess the impacts of favourable behavioural changes that have happened in the community. These behavioural impacts may be difficult to measure but can still be visible; therefore, the study shows the standardised factor loading for project impacts is $\mathrm{r}^{2}=0.61(\mathrm{p}<0.001)$ in project success.

Finally, project sustainability is identified for evaluating NGOs' project success, an area overlooked by previous literature. The NGO context is different from that of private organisations and they have been involved in remarkable number of different types of project 
for community development. Their project implementations have a wider range of locations, both within the country and internationally. NGOs undertake projects in communities and leave once the project is completed; however, after completion of these projects, work should continue in the community until the community becomes resilient. Therefore, they need to look into the sustainability of the project in the specific community. For example, if it is an income-generation project, they would see how long a business would be stable and how much income it would generate for a longer period in the community. The study shows a standardised factor loading for project sustainability is $\mathrm{r}^{2}=0.75(\mathrm{p}<0.001)$ in project success.

\subsection{Measuring NGO Organizational Success}

Past studies stressed that project success does not end with achieving scope, quality, time and budget parameters or meeting stakeholders' satisfaction and project impacts but it should also contribute to the business success of organisations (Serra and Kunc 2015; Sutton 2005; CookeDavies 2002). Subsequently, project success contributes to achieving organisational objectives and supporting business strategies to achieve organisations' competitive advantage (Cooke-Davies 2002; Shenhar et al. 1997). Literature informed the assessment factors of contribution to NGOs' vision, mission and objectives, which are stakeholders' rapport, NGOs’ reputation, and NGOs sustainability (Serra and Kunc 2015; Diallo and Thuillier 2005 2004; Cooke-Davies 2002; Shenhar et al. 2001). The survey study confirmed these four elements explain evaluation of NGO success.

Contribution to NGOs' vision, mission and objectives is identified as the first factor used to evaluate NGO success. Previous researchers emphasised projects should help to attain organisational objectives (Shenhar et al. 2001; Maloney 1990). The survey study shows a standardised factor loading for this resource is $r^{2}=0.83(\mathrm{p}<0.001)$ in NGO success. 
Stakeholders' rapport is considered the next factor for evaluating NGO success. Execution of projects should lead to increased strong connections with stakeholders, allowing NGOs to carry out future projects with strong support and advice from stakeholders. This suggests NGOs should strengthen relationships with their stakeholders for successful continuity of their operations. The study shows the standardised factor loading for stakeholders' rapport is $\mathrm{r}^{2}=0.59(\mathrm{p}<0.001)$ in NGO success.

NGOs' reputation is identified as the next measure used to evaluate NGOs' organizational success. Through increasing NGOs’ reputation, NGOs' abilities to raise funds from donors, government and the public will be increased. It is not surprising therefore that the study shows a standardised factor loading for NGOs' reputation is $\mathrm{r}^{2}=0.84(\mathrm{p}<0.001)$ in NGO success.

Finally, NGOs' sustainability is identified as a very important measure of NGO success, which was recognised as an important measure for international development projects (Diallo and Thuillier 2005, 2004). NGOs are not providing one-time support for the community but, instead, they need to continue their fullest support to the community for a long period. Therefore, NGO projects should contribute to their long-term sustainability, which assists NGOs' long-term survival. The study shows a standardised factor loading for NGOs' sustainability is $\mathrm{r}^{2}=0.61(\mathrm{p}<0.001)$ in NGO success.

The study identified four critical factors, contribution to NGOs' vision, mission and objectives, stakeholders' rapport, NGOs' reputation and NGOs sustainability, should be used to evaluate NGO success. This is the third level of NGO success explored as an important level for evaluating the overall project success of organisations. However, this was not 
empirically tested in the third, individual level by previous researchers. Therefore, as this study has highlighted, this is an important level for evaluating NGOs’ overall project success.

\subsection{Associations among the Three Levels of Project Success}

The SEM model identified relationships among the levels of project success which supported building and testing a valid model. The result shows the standardised coefficient is 0.75 between PM success and project success, confirming PM success has a very strong positive effect on project success. Whilst the existence of a relationship is not surprising, the strength of the association may indicate project managers in NGOs may be focused on the use of simplified quantitative metrics to manage and evaluate projects rather than complex, uncertain stakeholder satisfaction measures. Similar findings have been identified in private sector firms (Berssaneti and Carvalho 2015). Further, early work in ID project success has identified the perceived priority of short-term PM dimensions over longer-term project impact dimensions (Diallo and Thuillier 2004). As discussed earlier, NGOs not only need to meet the needs of diverse stakeholders but also face competitive pressures. These findings may indicate the need to provide verification to stakeholders, such as funders who require immediate feedback on the success of an initiative, may encourage NGO project managers to associate the overall success of a project strongly with its management dimensions. Since NGOs can also now compete with the private sector as social entrepreneurs, these organizations may use similar success measures and, when combined, they may result in the strong association between PM success and project success seen in this study.

The second highest association is a standardised coefficient of 0.63 between project success and NGO success, which indicates project success has a strong positive effect on NGO success. Whilst a relationship between benefits realisation activity and corporate success has been identified (Serra and Kunc 2015), this paper extends these findings to quantify the 
strength of association between organizational success and project success. Finally, the standardised coefficient between PM success and NGO success is 0.26 , which indicates that although there is a relationship between PM and NGO success, the relationship between other success dimensions is higher. This indicates that while short term success may be important for NGOs to maintain the confidence of funders, an established reputation for delivering favourable project outcomes may be more valuable to sustained organizational success.

\section{Conclusion}

The study produced a valid model of the assessment factors for project success into three levels in the development project context by NGOs. Considerable empirical studies have been completed previously in private and public organisations for assessing project success using the parameters of meeting scope, quality, time, budget, stakeholder satisfaction and project impacts (Sutton 2005; Schwalbe 2004; Pinkerton 2003; Thomsett 2002). However, the present study focused on assessing project success in three levels of PM success, project success and NGO success. Firstly, in PM success, four key elements consistent with previous studies were identified, namely, meeting scope, quality, time and budget. Secondly, in project success, three key elements of stakeholders' satisfaction, project impacts and project sustainability were discovered. Finally, in NGO success, four key elements, contribution to NGOs’ vision, mission and objectives, stakeholders’ rapport, NGOs’ reputation and NGOs’ sustainability were explored.

The present study identified the interconnections amongst the three levels of project success. The study shows significant relationships exist among the three levels of project success, in which the first level of PM success has strong effect on the second level of project success and moderate effect on the third level of NGO success. Further, the second level of project 
success has a strong effect on NGO success, which underlines only PM success is not guaranteed to achieve a high level of NGOs' success. Therefore, PM success and project success are vital to realising a high level of NGOs’ success.

The present study sought to establish a validated framework for assessing project success and show the interconnections amongst the three levels of project success by NGOs, contributing to academic research. The study provides extended knowledge in the domain of project success from a developing country’s context, i.e., Sri Lanka; however, it could be transferable to other development country settings. Previous studies were conducted in private sector organisations located mostly in a developed country's context. This study is conducted in a new setting of a post-conflict, post-disaster environment which may be applicable to other developing country contexts.

The study proposed a new validated framework for evaluating PM success and shows the connections among the levels of project success with the support of NGO development projects. Hence, NGO managers can develop new assessment schemes for project success that ultimately improve project delivery in NGOs.

Finally, the contributions and implications presented in this study can be valuable both to academic researchers and practitioners. NGOs face many challenges and difficulties in providing services and programmes to their communities, members, and beneficiaries in today’s competitive environment. Overall, the study enables NGO managers of development projects to understand the assessment factors for project success in different levels and their interconnections, which can aid the design of tools to support holistic assessment of success of development projects. It also calls for actual participation of many organisational 
development players to properly find the key domains of project success to improve project delivery by NGOs. 


\section{References}

Abdi, H., 2003. Factor rotations in factor analyses. Encyclopaedia for Research Methods for the Social Sciences. Sage: Thousand Oaks, CA.792-795.

Ahsan, K. and Gunawan, I., 2010. Analysis of cost and schedule performance of international development projects. International Journal of Project Management 28(1), 68-78.

Atkinson, R., 1999. Project management: Cost, time and quality, two best guesses and a phenomenon, it's time to accept other success criteria. International Journal of Project Management 17 (6), 337-342.

Baccarini, D., 1999. The Logical Framework Method for Defining Project Success. Project Management Journal, 30 (4) 25-32.

Bagci, C., 2003. Historical evolution of NGOs: NGO proliferation in the post-Cold War era. Avrupa Gunlugu, 4 299-326.

Banks, T., Richard, C., Ping, L. and Zhaoli, Y., 2003. Community-based grassland management in western China rationale, pilot project experience, and policy implications. Mountain Research and Development 23(2) 132-140.

Belassi, W., Kondra, A. and Tukel, O., 2007. New Product Development Projects: The Effects of Organizational Culture. Project Management Journal, 38 (4) 12-24.

Berssaneti, F. T., \& Carvalho, M. M., 2015. Identification of variables that impact project success in Brazilian companies. International Journal of Project Management, 33(3), 638649.

Brown, C. H., 2014. Survey Instruments Used to Evaluate Foundation-Funded Non-profit Capacity-Building Programs: Considerations for Organized Philanthropy. The Foundation Review, 6 (2), 5.

Bryman, A. and Cramer, D., 2009. Quantitative data analysis with SPSS 1415 and 16: A guide for social scientists. New York: Routledge. 
Byrne, B. M., 2010. Structural equation modelling with AMOS: Basic concepts, applications, and programming. 2nd edition. New York: Routledge.

Byrne, B. M., 2013. Structural equation modelling with AMOS: Basic concepts, applications, and programming. New York: Routledge.

Camilleri, E., 2012. Project success: Critical factors and behaviours. Surrey: Gower Publishing.

Carmines, E. G. and McIver, J. P., 1981. Analysing models with unobserved variables: Analysis of covariance structures. Social Measurement: Current Issues, 65-115.

Chin, W. W. and Newsted, P. R., 1999. Structural Equation Modelling analysis with small samples using partial least squares. In: Hoyle, R., ed., Statistical strategies for small sample research, London: Sage publications, 307-341.

Cooke-Davies, T., 2002. The "real" success factors in projects. International Journal of Project Management 20 (3) 185-190.

De Wit, A., 1988. Measurement of project success. International Journal of Project Management, 6 (3) 164-170.

Diallo, A. and Thuillier, D., 2004. The Success dimensions of international development projects: The perceptions of African project coordinators. International Journal of Project Management 22 19-31.

Diallo, A. and Thuillier, D., 2005. The success of international development projects, trust and communication: an African perspective. International Journal of Project Management 23 (3) 237-252.

Duncan, W., 1987. Get out from under. Computer world, 9, 89-93.

Easterly, W., 2009. How the millennium development goals are unfair to Africa. World Development, 37 (1) 26-35. 
Farrell, A. M., 2010. Insufficient discriminant validity: A comment on Bove, Pervan, Beatty, and Shiu (2009). Journal of Business Research, 63 (3), 324-327.

Garson, G. D., 2012. Testing Statistical Assumptions. Location: Statistical Association Publishing. Blue Book series.

Globerson, S. and Zwikael, O., 2002. The Impact of the Project Manager on Project Management Planning Processes. Project Management Journal, 33 (3), 58-64.

Golini, R. and Landoni, P., 2014. International development projects by non-governmental organizations: an evaluation of the need for specific project management and appraisal tools. Impact Assessment and Project Appraisal, 32 (2) 121-135.

Hair, J. F., Black, W. C., Babin, B. J. and Anderson, R. E., 2010. Multivariate data analysis. 7th edition. Upper Saddle River, NJ: Prentice-Hall.

Hair, J. F., Black, W. C., Babin, B. J., Anderson, R. E. and Tatham, R. L., 2006. Multivariate Data Analysis. 6th edition. Upper Saddle River, NJ: Prentice Hall.

Hartman, F. T., 2000. Don't park your brain outside: A practical guide to improving shareholder value with SMART project management. Upper Darby, Pen Hirai, Project Management Institute.

Hermann, M.G. and Pagé, C., 2016. Leadership and Behaviour in Humanitarian and Development Transnational Non-Governmental Organizations. Politics and Governance, 4(2),127-137.

Hermano, V., López-Paredes, A., Martín-Cruz, N. and Pajares, J., 2013. How to manage international development (ID) projects successfully. Is the PMD Pro1 Guide going to the right direction?. International Journal of Project Management, 31(1) 22-30.

Hinkin, T. R., 1998. A brief tutorial on the development of measures for use in survey questionnaires. Organizational Research Methods 1 (1) 104-121. 
Hoe, S. L., 2008. Issues and procedures in adopting structural equation modelling technique. Journal of Applied Quantitative Methods, 3 (1), 76-83.

Hopkins, W. G., 2008. Research designs: choosing and fine-tuning a design for your study. Sportscience 12 12-21.

Hoyle, R., 1995. Structural equation modelling: Concepts, issues and applications. Thousand Oaks, CA: Sage Publications.

Hu, L. and Bentler, P. M., 1999. Cut-off Criteria for Fit Indexes in Covariance Structure Analysis: Conventional Criteria versus New Alternatives. Structural Equation Modelling, 6 (1) $1-55$.

Ika, L. A., 2012. Project management for development in Africa: Why projects are failing and what can be done about it. Project Management Journal, 43 (4) 27-41.

Ika, L. A., Diallo, A. and Thuillier, D., 2010. Project Management in the international development industry: The project coordinator's perspective. International Journal of Managing Projects in Business, 3 (1), 61-93.

Ika, L. A., Diallo, A. and Thuillier, D., 2012. Critical success factors for World Bank projects: an empirical investigation. International Journal of Project Management, 30 (1) 105-116.

Jugdev, K. and Mathur, G., 2006. A Factor analysis of tangible and intangible project management assets. $4^{\text {th }}$ PMI Research Conference, Montreal, QC, PMI.

Kometa, S., Olomolaiye, P. O. and Harris, F. C., 1995. An evaluation of clients' needs and responsibilities in the construction process. Engineering, Construction and Architectural Management 2 (1), 45-56.

Lancaster, G. A., Dodd, S. and Williamson, P. R., 2004. Design and analysis of pilot studies: recommendations for good practice. Journal of Evaluation in Clinical Practice 10 (2), 307312. 
Lei, P.W. and Wu, Q., 2007. Introduction to structural equation modelling: Issues and practical considerations. Educational Measurement: issues and practice 26(3), 33-43.

Levy, P. S. and Lemeshow, S., 2009. Sampling of Populations: Methods and Applications: Solutions Manual. Wiley-Blackwell.

Liu, A. N. N. and Walker, A., 1998. Evaluation of project outcomes. Construction management and Economics 16 109-219.

Maloney, W. F., 1990. Framework for analysis of performance. Journal of Construction Engineering and Management. 116 (3), 399-415.

Mazzocchi, M., 2008. Statistics for marketing and consumer research. 1st edition. Sage.

Nanthagopan, Y., and Williams, N. (2016). Evaluation Factors of Project Success in NonGovernmental Organizations (NGOs). A paper presented in annual research symposium, NCAS, Sri Lanka, Nov 2016.

Nanthagopan, Y., Williams, N.L. and Page, S., 2016. Understanding the nature of Project Management capacity in Sri Lankan non-governmental organisations (NGOs): A Resource Based Perspective. International Journal of Project Management, 34(8), pp.1608-1624.

National Secretary for Non-Governmental Organizations 2014. Directory of Registered NGOs. Available from: http://www.ngosecretariat.gov.lk/web/index.php?option=com statistics\&Itemid=67\&lang=en [Accessed 7 January 2014].

Ngacho, C. and Das, D., 2014. A performance evaluation framework of development projects: An empirical study of Constituency Development Fund (CDF) construction projects in Kenya. International Journal of Project Management, 32(3), 492-507.

Njeri, D. N., \& Were, S., 2017. Determinants of project performance in non-governmental organizations in Kenya, a case study of hand in hand EASTERN AFRICA. International Journal of Project Management 1(4), 61-79. 
Papke-Shields, K.E., Beise, C., Quan, J., 2010. Do project managers practice what they preach, and does it matter to project success? International Journal of Project Management. 28, 650-662.

Pinkerton, W. J., 2003. Project Management: achieving project bottom-line success. New York: McGraw-Hill.

Pinto, J. K. and Slevin, D. P., 1988. Project success: definitions and measurement techniques. Project Management Institute.

Preston, C. C. and Colman, A. M., 2000. Optimal number of response categories in rating scales: reliability, validity, discriminating power, and respondent preferences. Acta Psychologica 104 (1) 1-15.

Qureshi, S. M., \& Kang, C. (2015). Analysing the organizational factors of project complexity using structural equation modelling. International Journal of Project Management, 33(1) 165-176.

Redmill, F., 1997. Software projects: Evolutionary vs. big-bang delivery. Chichester: Wiley. Schumacker, R. E. and Lomax, R. G., 2004. A beginner's guide to structural equation modeling. Psychology Press.

Schwalbe, K., 2004. Information Technology Project Management. 3rd edition. Boston, MA: Course Technology.

Serra, C. E. M., \& Kunc, M. (2015). Benefits Realisation Management and its influence on project success and on the execution of business strategies. International Journal of Project Management, 33(1), 53-66.

Shenhar, A. J., Dvir, D., Levy, O. and Maltz, A. C., 2001. Project success: a multidimensional strategic concept. Long Range Planning, 34 (6), 699-725.

Shenhar, A. J., Levy, O. and Dvir, D., 1997. Mapping the dimensions of project success, Project Management Journal 28 (2), 5-13. 
Shenhar, A. J., Tishler, A., Dvir, D., Lipovetsky, S. and Lechler, T., 2002. Refining the search for project success factors: A multivariate, typological approach. $R \& S$ Management, 32 (2) 111-126.

Sutton, B., 2005. Why Projects Fail - Mastering the Monster (Part 2) [online]. Location: publisher. Available from: http://www.itarchitect.co.uk/articles/display.asp?id=224 [Accessed 1 October 2012.

Teijlingen, E.V and Hundley, V., 2001. The Importance of Pilot Studies. Social Research Update, (35) 1-4

Thabane, L., Ma, J., Chu, R., Cheng, J., Ismaila, A., Rios, L. P. and Goldsmith, C. H., 2010. A tutorial on pilot studies: the what, why and how. BMC Medical Research Methodology 10 (1) 1 .

Thomsett, R., 2002. Radical project management. Upper Saddle River, NJ: Prentice Hall.

Torbica, Ž.M. and Stroh, R.C., 2001. Customer satisfaction in home building. Journal of Construction Engineering and Management 127(1), 82-86.

Tukel, O. and Rom, W.O., 2001. An empirical investigation of project evaluation criteria. International Journal of Operations \& Production Management 21(3), pp.400-416.

Tuman, J., 1986. Success modelling: A technique for building a winning project team. Proceedings of Project Management Institute 29-34.

ul Musawir, A., Serra, C.E.M., Zwikael, O. and Ali, I., 2017. Project governance, benefit management, and project success: Towards a framework for supporting organizational strategy implementation. International Journal of Project Management, 35(8), pp.1658-1672. UNDP 2014. Human Development Report 2014: Sustaining Human Progress: Reducing Vulnerabilities and Building Resilience. New York: United Nations Development Programme. Available from: http:/hdr.undp.org/sites/default/files/hdr14-report-en-1.pdf [Accessed 10 January 2015]. 
Weerawardena, J., McDonald, R. E. and Mort, G. S., 2010. Sustainability of non-profit organizations: An empirical investigation. Journal of World Business, 45 (4), 346-356.

Westhuizen, D. and Fitzgerald, E. P., 2005. Defining and measuring project success. European Conference on IS Management, Leadership and Governance, Reading, United Kingdom: Academic Conferences Limited. Available from: http://eprints.usq.edu.au/346/1/DependentVariableArticleV8.pdf [Accessed 12 February 2013].

Wheaton, B., 1987. Assessment of fit in over-identified models with latent variables. Sociological Methods \& Research 16 (1) 118-154. 


\section{Appendix 1: Examination of Previous Survey Tools related to Project Success}

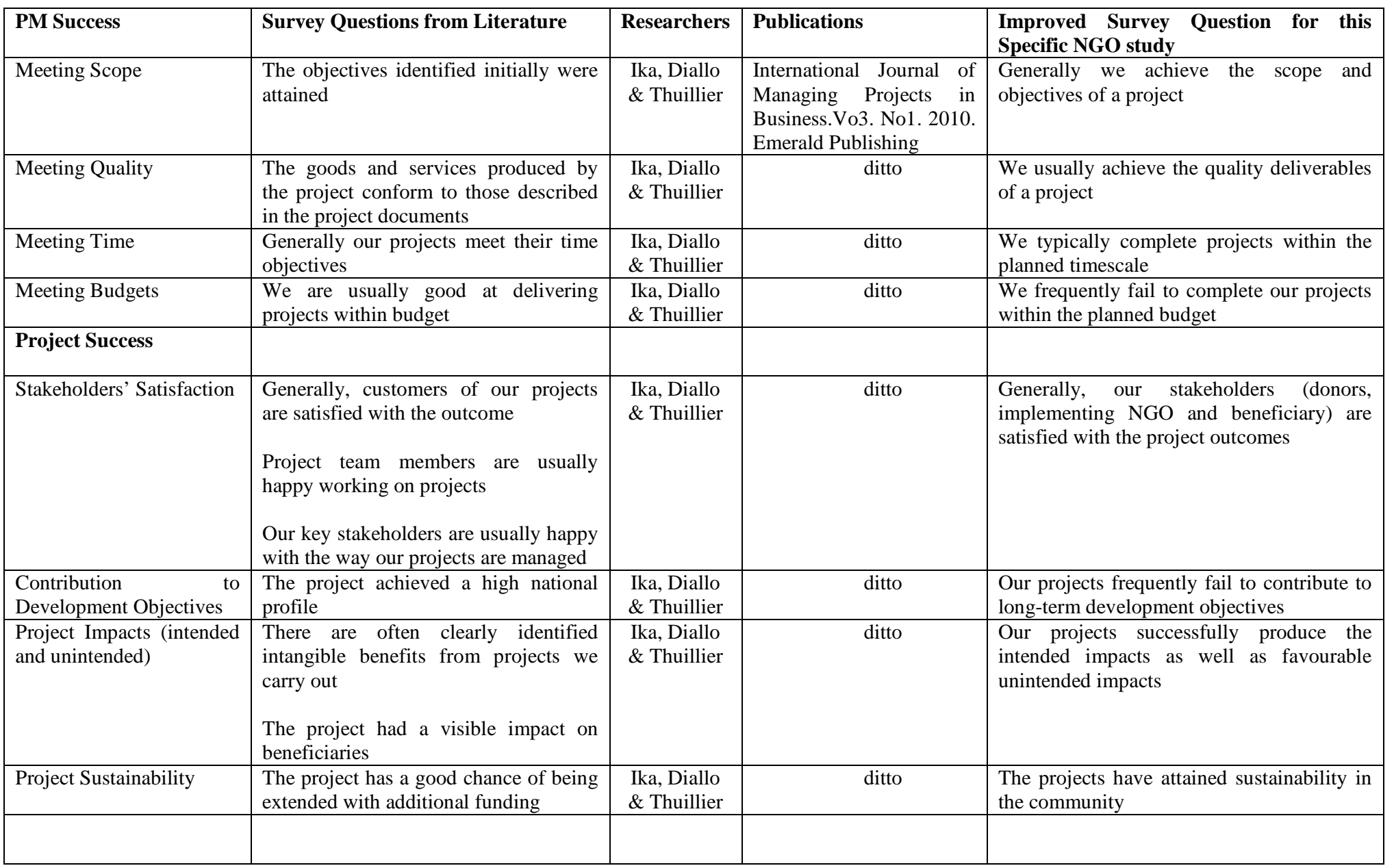




\begin{tabular}{|l|l|l|l|l|}
\hline NGOs Success & & & & \\
\hline $\begin{array}{l}\text { Contribution to NGOs' } \\
\text { Vision, Mission and } \\
\text { Objectives }\end{array}$ & $\begin{array}{l}\text { Our projects usually result in tangible } \\
\text { benefits for the organization }\end{array}$ & $\begin{array}{l}\text { Ika, Diallo } \\
\text { \& Thuillier }\end{array}$ & ditto & $\begin{array}{l}\text { Our projects contribute to achieving the } \\
\text { vision, mission and objectives of the } \\
\text { organization }\end{array}$ \\
\hline NGOs' Rapport & The project increased stakeholder links & $\begin{array}{l}\text { Ika, Diallo } \\
\text { \& Thuillier }\end{array}$ & $\begin{array}{l}\text { Our projects fail to increase long-term } \\
\text { rapport with our stakeholders }\end{array}$ \\
\hline NGOs' Reputation & $\begin{array}{l}\text { The project had a good reputation } \\
\text { among the principal donors }\end{array}$ & $\begin{array}{l}\text { Ika, Diallo } \\
\text { \& Thuillier } \\
\text { reputation of projects have improved the } \\
\text { stakeholders, government and general } \\
\text { public }\end{array}$ \\
\hline NGOs' Sustainability & $\begin{array}{l}\text { The project built an institutional } \\
\text { capacity within the country }\end{array}$ & $\begin{array}{l}\text { Ika, Diallo } \\
\text { \& Thuillier }\end{array}$ & $\begin{array}{l}\text { Our projects increased the fundraising } \\
\text { abilities and sustainability of the } \\
\text { organization }\end{array}$ \\
\hline
\end{tabular}




\section{Appendix 2: Project Success Assessment: Field Questionnaire}

\section{NGOs’ Project Success}

Project success can be defined as a project that meets its objectives within budget and on schedule, the expectations of stakeholders and supports organizational success. It can be evaluated at three levels as PM success, Project success and NGO success.

\section{PM Success}

PM success refers to the ability to achieve the project objectives, produce quality deliverables and complete the project within the planned timeframe and budget.

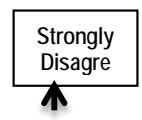

\section{PM Success}

$$
\begin{array}{lllllll}
1 & 2 & 3 & 4 & 5 & 6 & 7
\end{array}
$$

1 Generally we achieve the scope and objectives of a project.

2 We usually achieve the quality deliverables of a project. $\begin{array}{llllllll}1 & 2 & 3 & 4 & 5 & 6 & 7\end{array}$

3 We typically complete projects within the planned timescale.

4 We frequently fail to complete our projects within the planned budget.

$\begin{array}{lllllll}1 & 2 & 3 & 4 & 5 & 6 & 7\end{array}$ 


\section{Project Success}

Project success occurs when the project produces favourable impacts and stakeholders are satisfied with the project outcomes.

Project Success

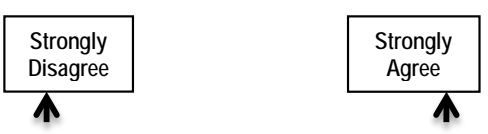

$\begin{array}{lllllll}1 & 2 & 3 & 4 & 5 & 6 & 7\end{array}$

5 Generally, our stakeholders (donors, implementing

NGO and beneficiary) are satisfied with the project $\begin{array}{llllllll}1 & 2 & 3 & 4 & 5 & 6 & 7\end{array}$ outcomes.

6 Our projects frequently fail to contribute to long-term $\begin{array}{llllllll}\text { development objectives. } & 1 & 2 & 3 & 4 & 5 & 6 & 7\end{array}$

7 Our projects successfully produce the intended impacts as well as favourable unintended impacts.

$\begin{array}{lllllll}1 & 2 & 3 & 4 & 5 & 6 & 7\end{array}$

$\begin{array}{lllllllll}8 & \text { The projects attained sustainability in the community. } & 1 & 2 & 3 & 4 & 5 & 6 & 7\end{array}$

\section{NGO Success}

NGO success occurs when the project has contributed to the NGO's success overall. The project contributes to achieving the organizational objectives, increasing stakeholders' rapport and reputation and helping to sustain the NGO for a long period. 
45

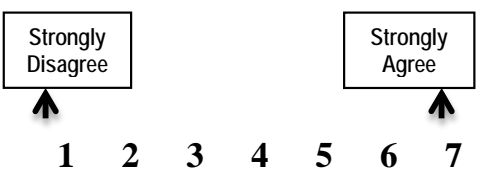

\section{NGO Success}

9 Our projects contribute to achieving the vision, mission and objectives of the organization.

$\begin{array}{lllllll}1 & 2 & 3 & 4 & 5 & 6 & 7\end{array}$

10 Our projects fail to increase long-term rapport with our stakeholders.

$\begin{array}{lllllll}1 & 2 & 3 & 4 & 5 & 6 & 7\end{array}$

11 Overall, our projects have improved the reputation of the organization amongst stakeholders, government and the public.

$\begin{array}{lllllll}1 & 2 & 3 & 4 & 5 & 6 & 7\end{array}$

12 Our projects have increased the fundraising abilities and sustainability of the organization.

$\begin{array}{lllllll}1 & 2 & 3 & 4 & 5 & 6 & 7\end{array}$ 